\title{
Investigating foliar fertiliser effects on the incidence of clover flea (Sminthurus viridis) damage on white clover
}

\author{
D.J. Wilson and P.J. Gerard \\ AgResearch, Ruakura Research Centre, Private Bag 3123, Hamilton, New Zealand \\ Corresponding author: derrick.wilson@agresearch.co.nz
}

\begin{abstract}
Clover flea (Sminthurus viridis (L.) is a sporadic and at times serious pest of white clover in New Zealand. Clover flea feeding is reduced in the laboratory by application of foliar fertilisers. The possibility that this was related to potassium status was tested in outdoor conditions using potted clover plants sprayed with two general purpose fertilisers, Nitrosol ${ }^{\circledR}$ and Thrive ${ }^{\circledR}$, potash, the insecticide diazinon and water. In one experiment, sprayed plants were placed in a paddock where clover flea were active while in the second, treated plants were surrounded by a barrier and clover flea released into the enclosure. Three treatments significantly reduced the incidence of feeding damage 7-9 days after treatment compared to the water treatment, with diazinon (42-57\% reduction in the incidence of damage) more effective than Nitrosol ${ }^{\circledR}(26-44 \%)$ and potash (38\%). There was no evidence the effect was related to potassium. Only Thrive ${ }^{\circledR}$ increased the amount of foliage.
\end{abstract}

Keywords clover flea, Sminthurus viridis, foliar fertiliser, Nitrosol ${ }^{\circledR}$, potash.

\section{INTRODUCTION}

Clover flea (Sminthurus viridis (L.) is a plantfeeding collembolan pest on a range of crops and in New Zealand causes sporadic and at times serious damage to white clover (Trifolium repens L.) in some northern North Island districts (Bell \& Willoughby 2003). Damage by clover flea is caused by rasping away the leaf epidermal surface so that it can feed on the underlying mesophyll. This creates characteristic window-like scars on the leaves. In cases of heavy infestation, only the veins and cuticle of the clover leaf remain and the amount of defecation can lead to feed refusal by stock (Pottinger 1983).

Clover flea development and abundance is highly dependent on moisture and temperature, and the life cycle can take as little as 28 days (Holdaway 1927; Wallace 1967; Dentener 1985). Clover flea aestivates as eggs over summer and nymphs emerge in autumn once temperature drops and rainfall occurs. The summer aestivation is relatively short in Waikato, allowing up to five generations a year, with populations peaking in spring (October/November)(Dentener 1985). Australian research has shown hatching can continue throughout summer under irrigation (Roberts et al. 2011).

Insecticidal control of clover flea is problematic because populations recover quickly in the absence of natural enemies (Townsend et al. 1979). Therefore multiple treatments or insecticide combinations including an insect growth regulator (IGR) are required to maintain clover production in affected pastures (Willoughby et al. 2002). Insecticides currently registered are the organophosphates fenitrothion, chlorpyrifos, diazinon and dimethoate and 
the IGR diflubenzuron (Young 2013). All these insecticides can disrupt biological control systems for other major New Zealand pasture pest species (Addison \& Barker 2006) so less disruptive controls are needed.

Previous research had indicated that application of Plant Plasma ${ }^{\circledR}$ and Nitrosol ${ }^{\circledR}$, organic foliar fertilisers based respectively on the waste from fish and meat processors, have the potential to reduce clover flea damage on white clover (Hardwick et al. 2007). Unlike conventional blood and bone fertiliser, Nitrosol ${ }^{\circledR}$ has added potassium $(\mathrm{K})$. It is possible the beneficial effect may be related to this additional $\mathrm{K}$ as high $\mathrm{K}$ levels have been repeatedly associated with reduced incidence of pests and diseases (Amtmann et al. 2008), with $\mathrm{K}$ being thought to play important roles in cell wall integrity, defence mechanisms and metabolism. For example, $\mathrm{K}$ content in maize leaves is so highly negatively correlated with the abundance of the spider mite Tetranycus cinnabarinus Boisduval that Nansen et al. (2013) proposed that determining $\mathrm{K}$ content by remote sensing could be used as a means to predict the risk of pest infestation.

This paper reports on two outdoor experiments using potted clover plants to compare the efficacy of recommended rates of organic (Nitrosol ${ }^{\circledR}$ ), inorganic (Thrive ${ }^{\circledR}$ ) and potash $\left(\mathrm{K}_{2} \mathrm{SO}_{4}\right)$ foliar fertilisers, with that of the organophosphate insecticide diazinon in reducing clover flea damage.

\section{MATERIALS AND METHODS}

Two randomised block pot trials were carried out at the Ruakura Research Centre, Hamilton, one in which treated pots were set out amongst permanent pasture infested with clover flea (field trial) and the other set out in an arena on mown grass (arena trial) that was then infested with field-collected clover flea.The data for both trials were log-transformed and analysed by ANOVA.

\section{Field trial}

Forty-day-old clover (cv. Grasslands Kopu II) seedlings were planted individually in $12 \mathrm{~cm}$ diameter plastic pots containing soil collected from the field trial paddock. Soil was used rather than commercial potting mix to closely simulate field conditions. In addition, the soil had low fertility, with a commercial laboratory test results showing deficiencies in all the major elements. Therefore any responses due to fertiliser should be more apparent than in potting mix. The plants were maintained in a shade house for 2 months then hardened outside for several days before spray treatments. Four treatments (Table 1) plus a water control were applied at the manufacturers' recommended rates to the potted clover plants using a $\mathrm{CO}_{2}$ powered, moving belt sprayer fitted with a single TeeJet 8001E nozzle and operated at $200 \mathrm{kPa}$ to apply 200 litres/ha. Plants were allowed to air dry before placing in the experimental sites with 20 replicates of each treatment.

On 19 November 2013, the treated pots were set out at $10 \mathrm{~cm}$ spacings in a randomised plot design in pasture that had been shut up for hay (Run 1). The pots were below sward height within an area containing abundant clover and clover flea. Weather conditions were dry and it was necessary to water the plants twice to maintain plant health. This was done by adding water to the side of the plants so as not to affect the foliar applications. After 7 days, the plants were removed for assessments in the laboratory. Damage was assessed by counting and inspecting every fully mature trifoliate leaf and recording whether or not it was damaged by clover flea. To determine whether the Nitrosol ${ }^{\circledR}$ treatment had altered leaf $\mathrm{K}$ levels, a subsample of leaves was taken from the control, Nitrosol ${ }^{\circledR}$ - and potashtreated plants, and their nutrient status analysed at a commercial laboratory using standard test methods.

There was a high level of slug damage so only damage clearly identifiable as clover flea was recorded. The trial was repeated as above with plants treated on 5 December 2013 using 10 replicates, and slug baits (Nufarm Slugout) were applied liberally around but not in the pots (Run 2). Plants were assessed 7 days after treatment as in Run 1. 
Table 1 Products, label rates and N-P-K values of treatments applied to clover plants.

\begin{tabular}{lccc}
\hline Treatment & Rate/litre & N-P-K & $\begin{array}{c}\text { Approximate amount } \\
\text { of K applied (g/litre) }\end{array}$ \\
\hline Control (water) & 0 & & \\
Nitrosol ${ }^{\circledR}$ (original liquid) Yates & $5 \mathrm{ml}$ & $8-3-6$ & 0.3 \\
${\text { Potash }\left(\mathrm{K}_{2} \mathrm{SO}_{4} \text { ) Tui }\right.}_{\text {Thrive }^{\circledR} \text { (All-purpose liquid) Yates }}^{23.3 \mathrm{~g}}$ & $0-0-42$ & 9.8 \\
Diazinon $(800$ EC) Nufarm & $5 \mathrm{ml}$ & $12-3-6.2$ & 0.3 \\
\hline
\end{tabular}

\section{Arena trial}

This trial was run concurrently with the Run 2 field trial (5 December 2013) and was almost identical to this trial, except it was set up on a $2 \mathrm{~cm}$ high mown grass sward in a rectangular arena constructed with $44 \mathrm{~cm}$ high corflute sides. Slug baits were applied liberally to the sward. After treatment, the pots were placed approximately $1 \mathrm{~cm}$ apart in the centre of the arena leaving $40 \mathrm{~cm}$ between the outside rows and the arena sides. This was done to encourage clover flea to move readily over and stay on the test pots. Large numbers of clover flea were collected from the field trial site with a Dolmar PB-250 blower vac and liberally applied over the potted plants. The plants were maintained for 9 days after treatment and assessed as above.

\section{RESULTS}

\section{Field trial}

The results from the field trial are summarised in Table 2. Diazinon was the most effective treatment in both trials, with the incidence of damage reduced to less than half that found on the controls $\left(57 \%\right.$ reduction). The Nitrosol ${ }^{\circledR}$ and potash treatments also significantly reduced damage by $44 \%$ and $38 \%$ overall respectively, compared to controls across the two runs. While there was no significant effect on damage observed on plants treated with Thrive ${ }^{\circledR}$, they tended to have more leaves than those treated with Nitrosol ${ }^{\circledR}$ in Run 2. No other treatment showed a growth response.

Levels of $\mathrm{K}$ in clover foliage from pasture are normally in the range of $2.5-3 \%$ dry weight. Due to the low soil fertility, the leaf analyses were well below this range and showed only minor responses to treatments (control 1.50\%, Nitrosol ${ }^{\circledR} 1.60 \%$ and potash $\left.1.68 \%\right)$.

\section{Arena trial}

The results from the arena trial (Table 3) were similar to those obtained in the field trial. Diazinon again was the most effective treatment (42\% less incidence of damage than on controls) followed by Nitrosol ${ }^{\circledR}$ (26\% reduction).

Table 2 Mean number of leaves/clover plant and mean percentage of leaves damaged after potted clover plants were given one of five foliar treatments and exposed to natural field populations of clover flea for 7 days.

\begin{tabular}{|c|c|c|c|c|c|}
\hline & \multicolumn{2}{|c|}{ Run 1 (20 reps) } & \multicolumn{2}{|c|}{ Run 2 (10 reps) } & \multirow{2}{*}{$\begin{array}{c}\text { Pooled } \\
\% \text { damaged }\end{array}$} \\
\hline & Leaves/plant & $\%$ damaged & Leaves/plant & $\%$ damaged & \\
\hline Control & 47.1 & 18.7 & 61.7 & 55.8 & 25.0 \\
\hline Nitrosol $^{\circledR}$ & 45.8 & 11.4 & 60.4 & 32.6 & 14.1 \\
\hline Potash & 48.7 & 12.2 & 65.0 & 43.3 & 15.5 \\
\hline Thrive ${ }^{\circledR}$ & 49.3 & 15.8 & 71.5 & 50.8 & 19.5 \\
\hline Diazinon & 51.2 & 8.2 & 63.1 & 23.6 & 9.2 \\
\hline $\operatorname{LSD}(\mathrm{P}=0.05)$ & 5.7 & 3.3 & 8.05 & 9.2 & 3.8 \\
\hline$P$ value & 0.389 & $\mathrm{P}<0.001$ & 0.068 & $\mathrm{P}<0.001$ & $\mathrm{P}<0.001$ \\
\hline
\end{tabular}

${ }^{1}$ back-transformed mean. 
Table 3 Mean number of leaves/clover plant and mean percentage of leaves damaged after potted clover plants were given one of five foliar treatments and exposed to artificially-seeded populations of clover flea in the field for 9 days.

\begin{tabular}{lcc}
\hline & Leaves/plant & \% damaged \\
\hline Control & 55.1 & 42.9 \\
Nitrosol $^{\circledR}$ & 55.1 & 31.5 \\
Potash $^{\circledR}$ & 56.8 & 36.9 \\
Thrive $^{\circledR}$ & 56.3 & 38.5 \\
Diazinon & 53.9 & 25.3 \\
& & \\
LSD (P=0.05) & 5.0 & 5 \\
P value & 0.80 & $\mathrm{P}<0.001$ \\
\hline
\end{tabular}

\section{DISCUSSION}

The results from these trials confirm the preliminary work by Hardwick et al. (2007) indicating that foliar application of the organic fertiliser Nitrosol ${ }^{\circledR}$ has some efficacy in protecting clover from clover flea damage for 7-9 days following application. Potash also showed some efficacy but neither fertiliser was as effective as diazinon at reducing the incidence of damage to clover leaves. The inorganic fertiliser Thrive ${ }^{\circledR}$ had no influence on damage but was the only fertiliser that boosted plant growth through foliar application. This fertiliser had the highest level of nitrogen $(\mathrm{N})$ and it is known that white clover shows marked response to foliar $\mathrm{N}$ application (Castle et al. 2007).

The effect of Nitrosol ${ }^{\circledR}$ did not appear to be due to its $\mathrm{K}$ content, as the rate of $\mathrm{K}$ that was applied in the Nitrosol ${ }^{\circledR}$ treatment was the same as that for Thrive ${ }^{\circledR}$ and very much lower than was applied in the potash treatment. Neither treatment was sufficient to elevate foliar $\mathrm{K}$ levels out of the deficient status within the time period assessed.

This latest study suggests that clover flea feeding behaviour changes when both organic and inorganic foliar fertilisers are applied to the clover. As a fertiliser made from blood and bone sourced from processing plants, Nitrosol ${ }^{\circledR}$ would contain many organic compounds that may have bioactivity. Some of these may have caused biochemical changes in the leaves as there is some evidence that foliar application of certain amino acids can induce resistance to fungal pathogens in curcubits (Ovadia et al. 2000) and the nematode Meloidogyne incognita in soyabeans (Glycine max (L.) Merr.)(Osman \& Viglierchio 1981). On the other hand, no rain had occurred during the trials and it is possible that the residues of the foliar fertilisers on the leaves were providing a protective barrier, either by repelling the insects or making it more difficult for the insects to get through the epidermal layers of the leaves to access the mesophyll.

While the production benefits of applying $\mathrm{K}$ fertilisers to pastures (Edmeades et al. 2010) and clover seed crops (Clifford \& Rolston 1990) on deficient soils are known, further research needs to be carried out on a farm scale to assess how effective organic fertilisers, such as Nitrosol ${ }^{\circledR}$, are at reducing the impact of clover flea damage in atrisk districts. This information could improve the cost:benefit ratio of incorporating such products into mainstream farm management systems.

In the long term, resistant clovers and/or biocontrol would be the best option for control of clover flea, should suitable agents be found. Some of the current insecticide options are being withdrawn, and their use in incompatible with biocontrol systems already in place in New Zealand pastures. Furthermore, the widespread use of irrigation on dairy pastures may increase the risk of clover flea damage in warmer east coast districts.

\section{ACKNOWLEDGEMENTS}

The authors thank Catherine Cameron for statistical analysis and the valuable input of both internal and external reviewers.

\section{REFERENCES}

Addison PJ, Barker GM 2006. Effect of various pesticides on the non-target species Microctonus hyperodae, a biological control agent of Listronotus bonariensis. Entomologia Experimentalis et Applicata 119: 71-79.

Amtmann A, Troufflard S, Armengaud P 2008. The effect of potassium nutrition on pest and disease resistance in plants. Physiologia Plantarum 133(4): 682-691. 
Bell NL, Willoughby BE 2003. A review of the role of predatory mites in the biological control of lucerne flea, Sminthurus viridis (L.) (Collembola: Sminthuridae) and their potential use in New Zealand. New Zealand Journal of Agricultural Research 46: 141-146.

Castle ML, Crush JR, Rowarth JS 2007. Effects of foliar and root applied nitrogen on nitrogen uptake and movement in white clover at low temperature. New Zealand Journal of Agricultural Research 50: 463-472.

Clifford PTP, Rolston MP 1990. Mineral nutrient requirements for white clover seed production. Journal of Applied Seed Production 8: 54-58.

Dentener PR 1985. The ecology of the lucerne flea Sminthurus viridus, in the South Auckland/ Waikato area. PhD thesis, University of Waikato. 289 pp.

Edmeades DC, Morton JD, Waller JE, Metherell AK, Roberts AHC, Carey P 2010. The diagnosis and correction of potassium deficiency in New Zealand pastoral soils: a review. New Zealand Journal of Agricultural Research 53: 151-173.

Hardwick S, Wilson DJ, Willoughby BE 2007. The effect of foliar fertilisers on clover flea (Sminthurus viridis (L.) (Collembola: Sminthuridae)) survival. New Zealand Plant Protection 60: 316 (abstract only).

Holdaway FG 1927. The bionomics of Smynthurus viridis, Linn., the South Australian lucerne flea. Pamphlet. Council for Scientific and Industrial Research, Melbourne, Commonwealth of Australia. 23 p.

Nansen C, Sidumo AJ, Martini X, Stefanova K, Roberts JD 2013. Reflectance-based assessment of spider mite "bio-response" to maize leaves and plant potassium content in different irrigation regimes. Computers and Electronics in Agriculture 97: 21-26.
Osman AA, Viglierchio DR 1981. Meloidogyne incognita development on soybean treated with selected amino acids by alternate methods. Revue de Nematologie 4: 172-174.

Ovadia A, Biton R, Cohen Y 2000. Induced resistance to downy mildew and Fusarium wilt in cucurbits. Acta Horticulturae 510: 55-59.

Pottinger RP 1983. Recent developments with pasture pests. Proceedings of the 35th Ruakura Farmers' Conference: 99-105.

Roberts JMK, Umina PA, Hoffmann AA, Weeks AR 2011. Population dynamics and diapause response of the springtail pest Sminthurus viridis (Collembola: Sminthuridae) in Southeastern Australia. Journal of Economic Entomology 104: 465-473.

Townsend RJ, Pottinger RP, Rowe SJ 1979. Evaluation of alternative insecticides for lucerne flea on pasture. Proceedings of the 32nd New Zealand Weed and Pest Control Conference: 68-71.

Wallace MMH 1967. The ecology of Sminthurus viridis (L.) (Collembola). I. Processes influencing numbers in pastures in Western Australia. Australian Journal of Zoology 15: 1173-1206.

Willoughby BE, Cooper B, Panckhurst K, Wilson DJ 2002. Combining chlorpyrifos and diflubenzuron for effective management of clover flea (Sminthurus viridis). New Zealand Plant Protection 55: 258-262.

Young S 2013. New Zealand Novachem Agricultural Manual. Agrimedia Ltd, Christchurch. 768 p. 